\title{
In vitro shoots multiplication from nodal explants of Sesame (Sesamum indicum L.)
}

\author{
Muhammad Asad ${ }^{1}$, Nadeem Ahmed ${ }^{1}$, Amir Sohail ${ }^{2 *}$, Tanveer Burni ${ }^{1}$, \\ Fazal Hadi ${ }^{1}$, Rehman Ali ${ }^{1}$, Muhammad Nauman Khan ${ }^{3}$, Abdullah Aziz ${ }^{1}$ \\ and Abbas Muhammad ${ }^{1}$
}

1. Department of Botany, University of Peshawar, Khyber Pakhtunkhwa-Pakistan

2. State Key Laboratory of Rice Biology, China National Rice Research Institute, Hangzhou-China

3. Department of Botany, Bacha Khan University Charsadda, KP-Pakistan

*Corresponding author's email:amirsohail@aup.edu.pk

Citation

Muhammad Asad, Nadeem Ahmed, Amir Sohail, Tanveer Burni, Fazal Hadi, Rehman Ali, Muhammad Nauman Khan, Abdullah Aziz and Abbas Muhammad. In vitro shoots multiplication from nodal explants of (Sesamum indicum L.). Pure and Applied Biology. Vol. 9, Issue 1, pp303-308. http://dx.doi.org/10.19045/bspab.2020.90035

\begin{tabular}{llll}
\hline \hline Received: 12/01/2019 & Revised: 06/09/2019 & Accepted: 23/10/2019 & Online First: 06/11/2019
\end{tabular}

\section{Abstract}

An effective micro propagation system has been developed efficiently through an enriched culture system for Sesamum indicum L. used as a medicinal plant and spicy crop significant from a nutritional point of view. The multiplication of shoot was obtained on Murashige and Skoog medium supplemented with $15 \mathrm{~g}$ 1-1 sucrose, $8 \mathrm{~g}$ l-1 agar and fortified with benzyl amino purine (BAP) in rabies of $0.1-1 \mathrm{mg} / 1$. The maximum number of young shoots was appeared on MS medium supplemented with $0.5 \mathrm{mg} / 1$ benzyl amino purine (BAP). Multiple combinations of harmonics were used for multiple inductions. Developed micro-shoots were shifted to culture medium supplemented with IAA $(1.0 \mathrm{mg} / 1)$ for efficient rooting. For hardening newly developed shoots were carried out and $71 \%$ were survived effectively. This system can be successfully applied for mass propagation of Sesamum indicum.

Keywords: BAP; Medium MS; Micro propagation; Multiple shoots; Sesame

\section{Introduction}

Sesame (Sesamum indicum L.) belongs to the family Pedaliaceae and known as the oldest crop of oilseeds. Seasame cultivated in Afghanistan India, Pakistan, Russia, China, South America and some African countries [1]. Through worldwide sesame cultivated on a total area of over 7.7 million hectares with entire production of 3.3 million tons [2]. Seeds of sesame are vital source of oil and used as spices. It consist of $48-58 \%$ of oil, it is very stable due to naturally occurring antioxidants sesamines, sesamol and sesamolin [3]. Sesame oil is used in the
Ayurvedic medicine system. Sesame seeds have antioxidant and antitumor potential. Due to abundant amount of protein the oil cake is used for livestock feed [4].

Sesamum indicum is highly uncooperative to regenerate in vitro conditions. Though, several procedures for micro propagation [5, 6], somatic embryos [7], and indirect regeneration of adventitious [8, 9], were achieved with low frequency. The productivity of Sesamum indicum L. is relatively low compared to other oleaginous crops because the cultivation of sesame is limited by poor soils $[10,11]$. The present 
study shows the results of an experiment to develop an appropriate procedure for the regeneration of multiple shoots in Sesamum indicum $\mathrm{L}$.

\section{In vitro mass propagation}

Plan tissue culture plays an important role in the study of a growing number of basic and practical programs in plant sciences [12]. Globally tissue culture techniques are used for plant conservation [13]. In this study we propose the conservation and rapid multiplication of Sesame for its use.

\section{Materials and methods}

Sesame (Sesamum indicum L.) seeds for experimental work have been obtained from the University of Agriculture of Peshawar. Seeds were germinated on Murashige and Skoog (MS) media. Media were $\mathrm{pH}$ adjusted before autoclaving at $121^{\circ} \mathrm{C}, 1 \mathrm{~atm}$. The cotton bed method was used with water and MS media for the in vitro regeneration of seedlings from seeds. All materials used in cultural work must be free of microbes. This is achieved by one of the following approaches: flame sterilization, $70 \%$ ethanol cleaning and other surface sterilants. The tip of shoot and the nodal region of in vitro derived seedlings were collected for the induction of multiple shootings. The surfacesterilized seeds were transferred to Murashige and Skoog (MS) medium integrated with $0.8 \%$ agar, $3 \%$ sucrose and $1 \%$ of myinositol. The media $\mathrm{pH}$ was adjusted to 5.7 and the maximum growth of the seedlings was observed and was subsequently sub cultured into the medium containing variable concentrations of BAP, IAA and NAA. The subculture process was carried out with the tip of the shoot and the nodal part of the plants. Therefore, It has been optimized with the maximum shoot lets formed from the sub cultured excised shoot tips. The maximum shooting length and internodes have been determined.

\section{Results and discussion}

The seeds that showed in vitro regeneration responded successfully. On the 2 nd day the seeds were germinated and from the 7 th day the maximum growth rate was reached. Plants grown in vitro have been used for in vitro cultivation studies [3]. The high frequency of germination was recorded on MS basal media similar results were obtained in the in vitro regeneration of Sesame by [14]. In Sesamum indicum L. both apical and all nodal segments were used as primary explants, the nodal explant is the most commonly used as explant to produce micro shoot [15, 16]. In recent study shoots multiplication from nodal explants was achieved on media supplemented with $0.5 \mathrm{mg}$ / 1 benzyl amino purine (BAP) and $1.5 \mathrm{mg} / 1$ of KIN show high frequency. (84\%) Of induction of multiple shoots (Table 3, Fig. 2). $88 \%$ Shoots multiplication was achieved by supplement media of $0.5 \mathrm{mg} / 1$ BAP and $1.5 \mathrm{mg} / 1$ NAA (Table 2). The same percentage $(88 \%)$ was also recorded in $0.5 \mathrm{mg} / 1 \mathrm{BAP}$ and $1.5 \mathrm{mg} / 1 \mathrm{IBA}$ media (Table 4). These results were in agreement with $[5,9$, 17].

The well-rooted seedlings were transferred to the potting mix in the ratio of sand: soil: farm manure in a 1: 1 ratio: $1.70 \%$ (Table 1) of the germination percentage was recorded.

In a recent experiment, an effective and reproducible procedure for the multiplication standardization of (Sesamum indicum L. CVV SVPR-1) was cultivated and formulated a comparatively efficient and reproducible shoot induction system has been worked out utilizing nodal and apical bud explants.Root induction was performed to increase the efficiency of sesame.

The study revealed that apical shoots and nodal segments for explantation were achieved in Sesamum indicum L. On Murashige and Skoog medium integrated with benzylaminopurin (BAP) (Table 5, Fig. 1). (0.5 mg / 1) more, Indole acetic acid (IAA) 
$(1.0 \mathrm{mg} / \mathrm{l})$.in vitro cultured micro shoots were successfully developed and transferred to the potting mix in the sand ratio: soil: courtyard manure (Fig. 3).

Table 1. Effect of BAP on multiplication of shoots per shoot tip cultured on MS media

\begin{tabular}{|c|c|c|c|c|}
\hline $\begin{array}{c}\text { Harmone } \\
\text { BAP(mg/l) }\end{array}$ & $\begin{array}{c}\text { Total No. of } \\
\text { explants }\end{array}$ & $\begin{array}{c}\text { No. of explants } \\
\text { responded }\end{array}$ & $\begin{array}{c}\text { Percentage of } \\
\text { responding cultures }\end{array}$ & M \pm SD \\
\hline 0.1 & 50 & 24 & $48 \%$ & $2.16 \pm 1.158$ \\
\hline 0.2 & 50 & 35 & $70 \%$ & $2.40 \pm 1.130$ \\
\hline 0.3 & 50 & 41 & $82 \%$ & $3.31 \pm 2.198$ \\
\hline 0.4 & 50 & 38 & $76 \%$ & $2.26 \pm 1.114$ \\
\hline 0.5 & 50 & 48 & $96 \%$ & $4.48 \pm 3.292$ \\
\hline 0.6 & 50 & 34 & $68 \%$ & $2.98 \pm 2.341$ \\
\hline 0.7 & 50 & 29 & $58 \%$ & $1.46 \pm 1.198$ \\
\hline 0.8 & 50 & 34 & $68 \%$ & $2.83 \pm 2.106$ \\
\hline 0.9 & 50 & 40 & $80 \%$ & $3.09 \pm 2.347$ \\
\hline 1.0 & 50 & 32 & $64 \%$ & $2.67 \pm 2.159$ \\
\hline
\end{tabular}

\section{Effect of different concentration of BAP on multiplication of shoots}

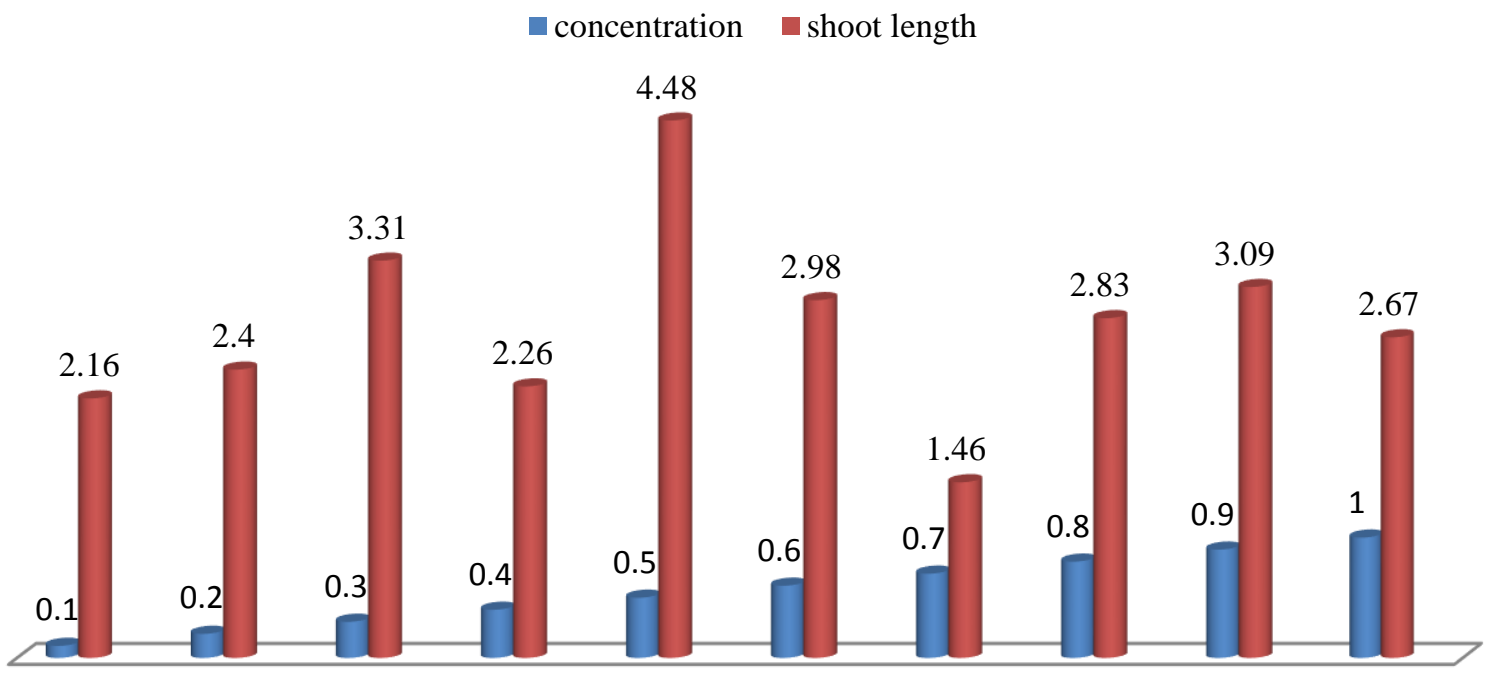

Figure 1. Effect of different concentration of BAP on multiplication of shoots

Table 2. Effect of BAP and NAA on multiplication of shoots per shoot tip as explants

\begin{tabular}{|c|c|c|c|c|c|}
\hline $\begin{array}{c}\text { Conc. of BAP } \\
(\mathbf{m g} / \mathbf{l})\end{array}$ & $\begin{array}{c}\text { Conc. of NAA } \\
(\mathbf{m g} / \mathbf{l})\end{array}$ & $\begin{array}{c}\text { Total No. of } \\
\text { explants }\end{array}$ & $\begin{array}{c}\text { Percentage of } \\
\text { responding } \\
\text { cultures }\end{array}$ & $\begin{array}{c}\text { Percentage of } \\
\text { responding } \\
\text { cultures }\end{array}$ & M \pm SD \\
\hline 0.5 & 0.5 & 50 & 32 & $64 \%$ & $3.27 \pm 2.742$ \\
\hline 0.5 & 1.0 & 50 & 38 & $76 \%$ & $3.16 \pm 2.483$ \\
\hline 0.5 & 1.5 & 50 & 44 & $88 \%$ & $4.45 \pm 3.946$ \\
\hline 0.5 & 2.0 & 50 & 23 & $46 \%$ & $2.54 \pm 2.06$ \\
\hline 0.5 & 2.5 & 50 & 18 & $36 \%$ & $1.78 \pm 1.53$ \\
\hline
\end{tabular}




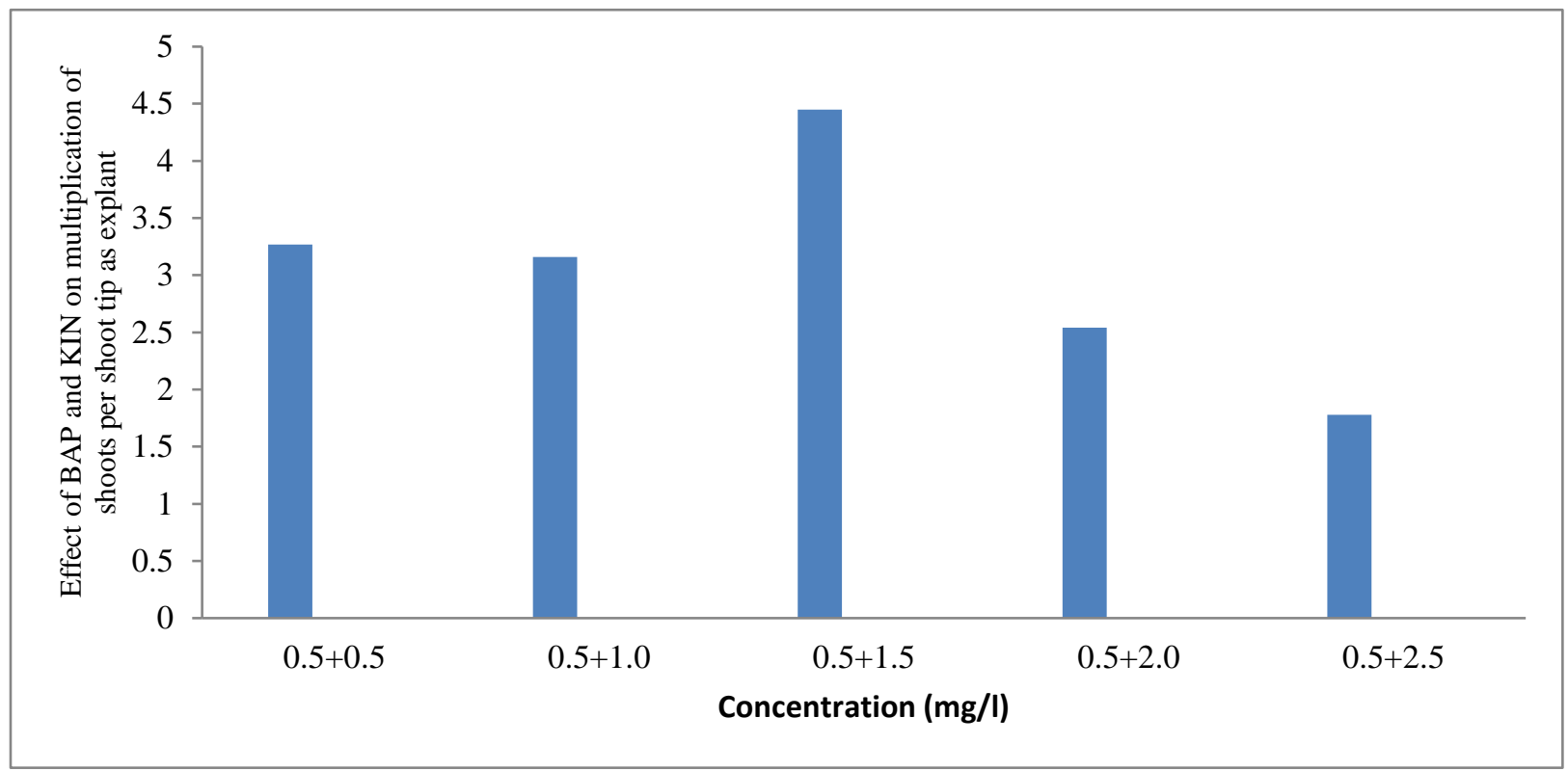

Figure 2. Effect of BAP and KIN on multiplication of shoots per shoot tip as explant

Table 3. Effect of BAP and KIN on multiplication of shoots per shoot tip as explants

\begin{tabular}{|c|c|c|c|c|c|}
\hline $\begin{array}{c}\text { BAP } \\
(\mathbf{m g} / \mathbf{l})\end{array}$ & $\begin{array}{c}\text { KIN } \\
(\mathbf{m g} / \mathbf{l})\end{array}$ & $\begin{array}{c}\text { Total No. of } \\
\text { explants }\end{array}$ & $\begin{array}{c}\text { No. of explants } \\
\text { responded }\end{array}$ & $\begin{array}{c}\text { Percentage of cultures } \\
\text { responding }\end{array}$ & $\mathbf{M} \pm$ SD \\
\hline 0.5 & 0.5 & 50 & 37 & $74 \%$ & $3.48 \pm 2.651$ \\
\hline 0.5 & 1.0 & 50 & 24 & $48 \%$ & $3.14 \pm 2.63$ \\
\hline 0.5 & 1.5 & 50 & 42 & $84 \%$ & $4.66 \pm 3.254$ \\
\hline 0.5 & 2.0 & 50 & 20 & $40 \%$ & $2.87 \pm 2.16$ \\
\hline 0.5 & 2.5 & 50 & 15 & $30 \%$ & $2.38 \pm 1.59$ \\
\hline
\end{tabular}

Effect of IAA on induction of roots in the microshoots

concentration shoot length

6.12

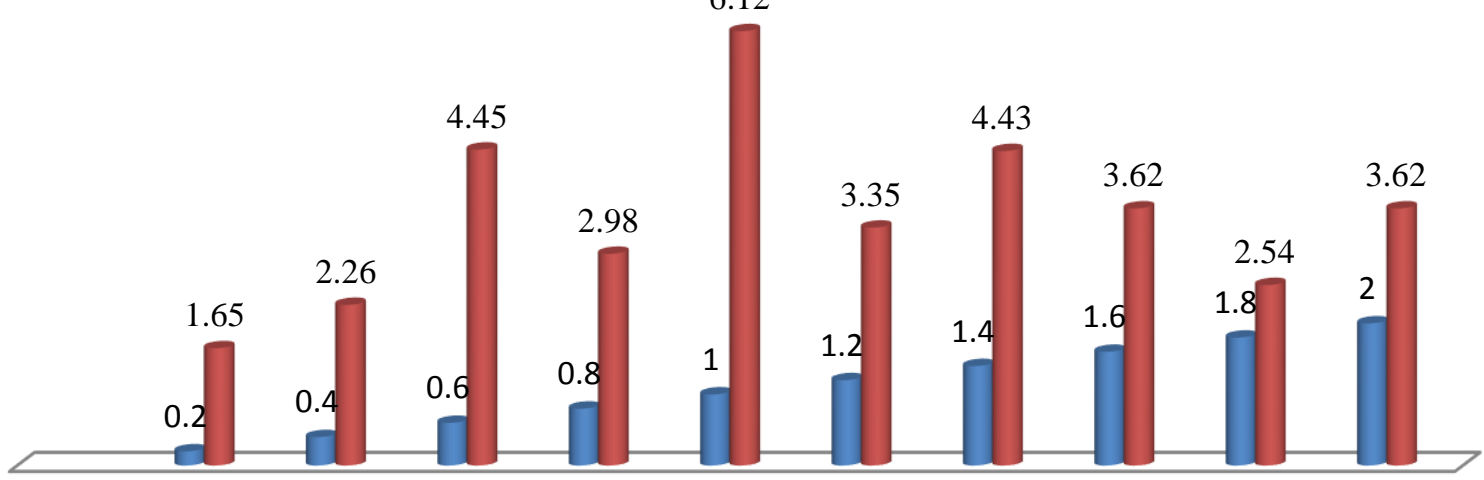

Figure 3. Effect of IAA on induction of roots in the micro shoots 
Table 4. Effect of BAP and IBA on multiplication of shoot per shoot tip as explants

\begin{tabular}{|c|c|c|c|c|c|}
\hline $\begin{array}{c}\text { BAP } \\
(\mathbf{m g} / \mathbf{l})\end{array}$ & $\begin{array}{c}\text { IBA } \\
(\mathbf{~ m g / l})\end{array}$ & $\begin{array}{c}\text { Total No. of } \\
\text { explants }\end{array}$ & $\begin{array}{c}\text { No. of explants } \\
\text { responded }\end{array}$ & $\begin{array}{c}\text { Percentage of } \\
\text { responding cultures }\end{array}$ & $\mathbf{M} \pm \mathbf{S D}$ \\
\hline 0.5 & 0.5 & 50 & 25 & $50 \%$ & $3.83 \pm 2.492$ \\
\hline 0.5 & 1.0 & 50 & 18 & $36 \%$ & $3.36 \pm 2.571$ \\
\hline 0.5 & 1.5 & 50 & 44 & $88 \%$ & $4.57 \pm 3.635$ \\
\hline 0.5 & 2.0 & 50 & 27 & $54 \%$ & $3.68 \pm 2.051$ \\
\hline 0.5 & 2.5 & 50 & 37 & $74 \%$ & $3.24 \pm 2.856$ \\
\hline
\end{tabular}

Table 5. Effect of IAA on root induction per shoot tip cultured on MS medium

\begin{tabular}{|c|c|c|c|c|}
\hline $\begin{array}{c}\text { Hormone } \\
\text { IAA(mg/l) }\end{array}$ & $\begin{array}{c}\text { Total No. of } \\
\text { explants }\end{array}$ & $\begin{array}{c}\text { No. of explants } \\
\text { responded }\end{array}$ & $\begin{array}{c}\text { Percentage of } \\
\text { responding cultures }\end{array}$ & M \pm SD \\
\hline 0.2 & 50 & 18 & $36 \%$ & $1.65 \pm 0.986$ \\
\hline 0.4 & 50 & 23 & $46 \%$ & $2.26 \pm 2.187$ \\
\hline 0.6 & 50 & 36 & $72 \%$ & $4.45 \pm 3.685$ \\
\hline 0.8 & 50 & 22 & $44 \%$ & $2.98 \pm 2.602$ \\
\hline 1.0 & 50 & 45 & $90 \%$ & $6.12 \pm 5.062$ \\
\hline 1.2 & 50 & 21 & $42 \%$ & $3.35 \pm 2.517$ \\
\hline 1.4 & 50 & 29 & $58 \%$ & $4.43 \pm 3.253$ \\
\hline 1.6 & 50 & 18 & $36 \%$ & $3.62 \pm 2.163$ \\
\hline 1.8 & 50 & 14 & $28 \%$ & $2.54 \pm 1.967$ \\
\hline 2.0 & 50 & 27 & $54 \%$ & $3.62 \pm 2.385$ \\
\hline
\end{tabular}

\section{Conclusion}

Our Present performance determine the culture conditions for micro propagation of sesame plant and concluded that shoot regeneration of Sesamum indicum L. were achieved in vitro on MS medium which containing different concentrations of cytokinins and auxins. It is also suggested that high frequency of shoot growth will be achieved by means of BAP, IBA and IAA application. This work will be also provide a helpful tool for genetic transformation and reproductive growth and for others tissue culture studies.

\section{Authors' contributions}

Conceived and designed the experiments: N Ahmed, Performed the experiments: M Asad, Analyzed the data: T Burni, F Hadi, R Ali \& MN Khan, Contributed materials/ analysis/ tools: A Aziz \& A Muhammad, Wrote the paper: A Sohail.

\section{References}

1. Michael MND, Joseph PND \& Lara P (2005). The Encyclopedia of Healing Foods. Publisher: Atria, 1st Edition.

2. FAOSTAT (2008). http://faostat.fao.org.

3. Brar GS \& Ahuja KL (1979). Sesame: its culture, genetics, breeding and biochemistry. In: C.P. Malik (ed.). Annual Review Plant Science, Kalyani Publishers, New Delhi. 245-313.

4. Osawa T, Kumon H, Namiki M, Kawakishi S \& Fukuda Y (1990). Antimutagenic heat-stable antioxidants, in Mutagens and Carcinogens in the Diet. Edited by MW Pariza, HU Aeschbacher, JS Felton and S Sato. Wiley-Liss, New York. pp 223-238.

5. Rao KR \& Vaidyanath K (1997). Induction of multiple shoots from seedling shoot tips of different varietiesof Sesamum. Indian $J$ of Plant Physiol 2: 257-261.

6. Gangopadhyay G, Poddar R \& Gupta S (1998). Micropropagation of sesame 
(Sesamum indicum L.) by in vitro multiple shoot production from nodal explants. Phytomorphol 48: 83-90.

7. Jeyamary R \& Jayabalan N (1997). Influence of growth regulators on somatic embryogenesis in sesame. Plant Cell, Tissue and Organ Cult 49: 67-70.

8. Taskin KM \& Turgut K (1997). In vitro regeneration of sesame (Sesamum indicum L.). Turk J of Bot 21: 15-18.

9. Younghee K (2001). Effects of BA, NAA, 2, 4-D and AgNO3 treatments on the callus induction and shoot regeneration from hypocotyl and cotyledon of sesame (Sesamum indicum L.). J of the Korean Soc for Horticul Sci 42: 70-74.

10. George L, Bapat VA \& Rao PS (1987). In vitro multiplication of sesame (Sesamum indicum) through tissue culture. Annual Bot 60: 17-21.

11. Evans DA, Sharp WR \& Bravo JE (1984). Cell culture methods for crop improvement. In: In Handbook of plant cell culture: crop species. Eds. WR Sharp, DA Evans, PVA mmirato and
Yamada Y Macmillan Publishing Co, New York. 47-68.

12. Gonzáles RG, Quiroz K, Carrasco B \& Caligari P (2010). Plant tissue culture: Current status, opportunities and challenges. Cien Inv Agr 37(3): 5-30.

13. Kale VP (2005). In vitro studies in capsicum (Capsicum annuum L.). Indian $J$ of Genetics 65(4): 329-330.

14. Baskaran P \& Jayabalan N (2006). In vitro mass propagation and diverse callus orientation on Sesamum indicum L. - an important oil plant. J Agric Tech 2: 259-269.

15. Lokesha R, Shashidhara N \& Janagoudar BS (2007). Callus induction and plant regeneration in Sesame (Sesamum indicum L.) through direct seeding. Plant cell Biotech Mol Bio 8(2): 85-88.

16. Ganesh R, Sharma A, Joshim A, Nanawati GC \& Simlot MM (1993). Callus cultures from sesame seed explants. Annual Agric Res 14: 388-391.

17. Reddy KRK \& Bahadur, B (1989). In vitro multiplication of castor. Recent advances in genetics and cytogenetics. Plant Tissue Culture 4(3): 479-82. 